\title{
New Negative-type Photosensitive Alkaline-developable Semi-aromatic Polyimides with Low Dielectric Constants Based on Poly(amic acid) from Aromatic Diamine Containing Adamantyl Units and Alicyclic Dianhydrides, A Cross-linker, and A Photoacid Generator
}

\author{
Yasufumi Watanabe, Yuji Shibasaki, Shinji Ando, and Mitsuru UedA ${ }^{\dagger}$ \\ Department of Organic \& Polymeric Materials, Graduate School of Science and Engineering, \\ Tokyo Institute of Technology, 2-12-1-H120 O-okayama, Meguro-ku, Tokyo 152-8552, Japan
}

(Received October 21, 2004; Accepted February 1, 2005; Published April 15, 2005)

\begin{abstract}
A new negative-working and alkaline-developable photosensitive polyimide precursor based on semi-aromatic poly(amic acid)s (4), 4,4'-methylenebis[2,6-bis(hydroxymethyl)]phenol (MBHP) as a cross-linker, and a photoacid generator (5-propylsulfonyloxyimino-5H-thiophen-2-ylidene)-2-(methylphenyl)acetonitrile (PTMA) has been developed. Novel polymers 4 were prepared by ring-opening polyadditions of alicyclic dianhydrides (1), 1,2,3,4-cyclobutanetetracarboxylic dianhydride (1a), bicyclo[2.2.2] oct-7-ene-2,3;5,6-tetracarboxylic dianhydride (1b), and bicyclo[2.2.1]heptane-2-methanecarboxylic-3,5,6-tricarboxylic-2,3:5,6-dianhydride (1c) with 1,3-bis(4-aminophenoxy)adamantane (3). Polymers 4 were converted to corresponding poly(imide)s (5) by thermal treatment. The dielectric constants $(\varepsilon)$ of $\mathbf{5}$ estimated from the refractive indices were 2.72-2.74. The photosensitive polyimide precursor containing 4 (60 wt \%), MBHP (30 wt \%), and PTMA (10 wt \%) cast from 2-methoxyethanol solution showed a clear negative image featuring $15 \mu \mathrm{m}$ line and space patterns when it was exposed to $436 \mathrm{~nm}$ light, post-exposure baked at $110^{\circ} \mathrm{C}$ for $3 \mathrm{~min}$, followed by developing with $2.38 \mathrm{wt} \%$ aqueous tetramethylammonium hydroxide (TMAH) solution at $25^{\circ} \mathrm{C}$ for $40 \mathrm{~s}$. [DOI $10.1295 /$ polymj.37.270]

KEY WORDS Polyimides / Alkaline Developer / Photosensitive Polymer / Refractive Indices / Low Dielectric Constants / Alicyclic /
\end{abstract}

Photosensitive polyimides (PSPIs) are widely used as protection and insulation materials in microelectronics because of their excellent properties such as thermal and chemical stabilities, a low dissipation factor, and a reasonably low dielectric constant $(\varepsilon)$. They are also attractive because they simplify processing and avoid the use of photoresist in the microelectric industry. ${ }^{1}$ Recently, poly(imide)s (PIs) having low $\varepsilon$ are required to increase the circuit speed.

Incorporation of fluorinated substituents into polymers decreases $\varepsilon$ due to the small dipole and the low polarizability of CF bond. Thus, many fluorinated polyimides have been reported. ${ }^{2}$ On the other hand, bulky units are also effective to decrease $\varepsilon$ because of the increase of molar volume. Thus, semi-aromatic PIs containing alicyclic structures have been developed as PIs with low $\varepsilon{ }^{3-14} \mathrm{~A}$ series of works by Chern et al. revealed that nonfluorinated aromatic polyimides derived from aromatic diamines containing adamantyl and diamantyl units show low $\varepsilon$ values ranging from 2.6 to 2.9. ${ }^{15-20}$ Semi-aromatic PIs based on adamantyl units would be better candidates for thermally stable and low dielectric materials.

This paper describes the synthesis of new semi-ar- omatic PIs from alicyclic dianhydrides with aromatic diamine containing an adamantly unit, and their application to new negative working alkaline developable PSPIs having low $\varepsilon$.

\section{EXPERIMENTAL}

\section{Materials}

1-Methyl-2-pyrrolidinone (NMP), N,N-dimethylacetamide (DMAc) were purified by the usual manner, and stored under an atmosphere of $\mathrm{N}_{2}$. 1,2,3,4-Cyclobutanetetracarboxylic dianhydride (1a) and bicyclo[2.2.2] oct-7-ene-2,3;5,6-tetracarboxylic dianhydride (1b) were purified by recrystallization from acetic anhydride and dried at $150{ }^{\circ} \mathrm{C}$ under vacuum before use. Bicyclo[2.2.1]heptane-2-methanecarboxylic3,5,6-tricarboxylic-2,3:5,6-dianhydride (1c) was heated to $90{ }^{\circ} \mathrm{C}$ in acetic anhydride and toluene, stirred for $1 \mathrm{~h}$, filtered, and then dried at $90^{\circ} \mathrm{C}$ for $1 \mathrm{~h}$ under vacuum prior to use. A photoacid generator (5-propylsulfonyloxyimino- $5 H$-thiophen-2-ylidene)-2-(methylphenyl)acetonitrile (PTMA) was donated by Ciba Specialty Chemicals K.K., and used without further purification. ${ }^{21} \mathrm{~A}$ cross-linker, 4,4'-methylenebis[2,6-

${ }^{\dagger}$ To whom correspondence should be addressed (E-mail: mueda@polymer.titech.ac.jp). 
bis(hydroxymethyl)]phenol (MBHP) was prepared according to a reported procedure..$^{22}$ Other reagents were obtained commercially and used as received.

\section{Measurements}

Infrared (IR) spectra were recorded on a Horiba FT-720 spectrophotometer. ${ }^{1} \mathrm{H}$ NMR spectra were obtained using a BRUKER DPX300 $(300 \mathrm{MHz})$ spectrometer. UV-vis spectra of polyimide films were recorded on a Jasco V-560 spectrophotometer. Thermogravimetry (TG) and differential scanning calorimetry (DSC) were performed with a Seiko TG/ DTA 6300 and DSC 6200, respectively. The film thickness was measured by a Dektak ${ }^{3}$ surface profiler (Vecco Instrument Inc). Refractive indices of polyimide films formed on quartz substrates were measured at a wavelength of $1.320 \mu \mathrm{m}$ at room temperature with a Metricon model PC-2000 prism coupler. Using linearly-polarized laser light with parallel (TE: transverse electric) and perpendicular (TM: transverse magnetic) polarization to the film plane, the in-plane $\left(n_{\mathrm{TE}}\right)$ and out-of-plane $\left(n_{\mathrm{TM}}\right)$ refractive indices and the film thickness of the samples were determined.

\section{Dissolution Rate}

MBHP and PTMA were added to a polymeric solution in 2-methoxyethanol (17 wt \% of the total solid) to construct a photosensitive polymer. The polymer film spin-cast on a silicon wafer was pre-baked at $80^{\circ} \mathrm{C}$ for $5 \mathrm{~min}$, and then exposed to a filtered super high pressure mercury lamp. The exposed film was developed with $2.38 \mathrm{wt} \%$ aqueous tetramethylammonium hydroxide (TMAH) solution at $25^{\circ} \mathrm{C}$ for $40 \mathrm{~s}$. The changes in the film thickness against the exposure energy were measured with a Dektak ${ }^{3}$ surface profiler (Vecco Instument Inc.).

\section{Photosensitivity}

A 2.7- $\mu$ m-thick polymer film on a silicon wafer was exposed to irradiation at a wavelength of $436 \mathrm{~nm}$ through the filtered super high pressure mercury lamp, developed with $2.38 \mathrm{wt} \%$ aqueous TMAH solution at $25^{\circ} \mathrm{C}$, and rinsed with water. A characteristic curve was obtained by a normalized film thickness against exposure energy.

\section{Synthesis of 1,3-Bis(4-nitrophenoxy)adamantane (2)}

Sodium hydride $(0.982 \mathrm{~g}, 40.9 \mathrm{mmol})$ was placed in a flask charged with dry $\mathrm{N}_{2}$. A solution of 1,3adamantane diol $(3.13 \mathrm{~g}, 18.6 \mathrm{mmol})$ in dry DMAc $(30 \mathrm{~mL})$ was added to the flask at $0{ }^{\circ} \mathrm{C}$ and the mixture was stirred for $30 \mathrm{~min}$ at this temperature. To this mixture, 4-fluoronitrobenzene $(5.61 \mathrm{~g}, 40.9 \mathrm{mmol})$ was added dropwise and the resulting mixture was warmed to room temperature. After stirring at this temperature for $4 \mathrm{~h}$, the mixture was poured into water. The precipitate was collected by filtration and recrystallized from acetone to give yellow crystals. The yield was $3.38 \mathrm{~g}$ (yield 44\%): mp $145-147^{\circ} \mathrm{C}$. IR (KBr, v): $2966(\mathrm{C}-$ H), $2924(\mathrm{C}-\mathrm{H}), 2866(\mathrm{C}-\mathrm{H}), 1589$ ( $\mathrm{Ar}), 1512\left(\mathrm{NO}_{2}\right)$, 1493 (Ar), $1342\left(\mathrm{NO}_{2}\right), 1253(\mathrm{C}-\mathrm{O}-\mathrm{C}) \mathrm{cm}^{-1} \cdot{ }^{1} \mathrm{H}$ NMR $\left(\mathrm{CDCl}_{3}, \delta, \mathrm{ppm}\right): 8.18(\mathrm{~d}, J=9.3 \mathrm{~Hz}, 4 \mathrm{H}$, ArH), 7.09 (d, $J=9.0 \mathrm{~Hz}, 4 \mathrm{H}, \operatorname{ArH}), 2.45(\mathrm{~s}, 2 \mathrm{H})$, $2.17(\mathrm{~s}, 2 \mathrm{H}), 1.90(\mathrm{~s}, 8 \mathrm{H}), 1.54$ (s, 2H). Anal. Calcd for $\left(\mathrm{C}_{22} \mathrm{H}_{22} \mathrm{~N}_{2} \mathrm{O}_{6}\right): \mathrm{C}, 64.38 ; \mathrm{H}, 5.40 ; \mathrm{N}, 6.83 ; \mathrm{O}$, 23.39. Found: C, 64.30; H, 5.48; N, 6.85; O, 23.30.

Synthesis of 1,3-Bis(4-aminophenoxy)adamantane (3)

A $300-\mathrm{mL}$ three-necked round-bottomed flask was charged with $2(6.68 \mathrm{~g}, 16.3 \mathrm{mmol})$, hydrazine monohydrate $(45 \mathrm{~mL})$, and a mixture of DMAc and ethanol $(150 \mathrm{~mL})$ (volume ratio, DMAc/ethanol $=2 / 1)$, and $0.18 \mathrm{~g}$ of $10 \%$ palladium on carbon (Pd-C). The mixture was refluxed for $16 \mathrm{~h}$, and then filtered to remove the Pd-C. The filtrate was poured into water. The precipitate was recrystallized from 1,4-dioxane, and the brown plate crystal was dried in vacuo at $160^{\circ} \mathrm{C}$ for $12 \mathrm{~h}$. The yield was $3.61 \mathrm{~g}$ (yield 76\%): $\mathrm{mp} \mathrm{184-}$ $186^{\circ} \mathrm{C}$. IR (KBr, v): 3444, $3359\left(\mathrm{NH}_{2}\right), 2943(\mathrm{C}-\mathrm{H})$, $2927(\mathrm{C}-\mathrm{H}), 2854(\mathrm{C}-\mathrm{H}), 1631\left(\mathrm{ArNH}_{2}\right), 1604,1504$ (Ar), $1200(\mathrm{C}-\mathrm{O}-\mathrm{C}) \mathrm{cm}^{-1} \cdot{ }^{1} \mathrm{H} \mathrm{NMR}\left(\mathrm{CDCl}_{3}, \delta, \mathrm{ppm}\right)$ : $6.76(\mathrm{~d}, J=8.7 \mathrm{~Hz}, 4 \mathrm{H}, \operatorname{ArH}), 6.57(\mathrm{~d}, J=9.0 \mathrm{~Hz}$, 4H, $\mathrm{ArH}), 3.52$ (s, 4H, NH 2 ), 2.31 (s, 2H), $1.94(\mathrm{~s}, 2 \mathrm{H})$, $1.71(\mathrm{~s}, 8 \mathrm{H}), 1.42(\mathrm{~s}, 2 \mathrm{H})$. Anal. Calcd for $\left(\mathrm{C}_{22} \mathrm{H}_{26^{-}}\right.$ $\mathrm{N}_{2} \mathrm{O}_{2}$ ): C, 75.40; H, 7.48; N, 7.99. Found: C, 75.22; $\mathrm{H}, 7.24 ; \mathrm{N}, 7.93$.

\section{Poly(amic acid)s (4)}

A flame-dried $20 \mathrm{~mL}$ flask was charged with $\mathbf{3}$ $(0.403 \mathrm{~g}, 1.15 \mathrm{mmol})$ and NMP $(2.80 \mathrm{~g})$ under nitrogen. Dianhydride 1c $(0.288 \mathrm{~g}, 1.15 \mathrm{mmol})$ was added to this solution at $25^{\circ} \mathrm{C}$ in one portion. The solution was stirred at this temperature for $7 \mathrm{~h}$ and then $65^{\circ} \mathrm{C}$ for $23 \mathrm{~h}$ under nitrogen. The inherent viscosity of the resulting polymer was $0.33 \mathrm{dL} / \mathrm{g}$, measured at a concentration of $0.5 \mathrm{~g} / \mathrm{dL}$ in NMP at $30^{\circ} \mathrm{C}$. IR $(\mathrm{KBr}): v=$ $1708(\mathrm{C}=\mathrm{O}$, carboxylic acid $), 1670(\mathrm{C}=\mathrm{O}$, amide $)$ $\mathrm{cm}^{-1}$.

\section{Poly(imide)s (5)}

The polyimide film was prepared by casting the solution of the polymer $\mathbf{4}$ on a silicon wafer at room temperature and then by heating at $70^{\circ} \mathrm{C}$ for $2 \mathrm{~h}$, $160^{\circ} \mathrm{C}$ for $1 \mathrm{~h}, 250^{\circ} \mathrm{C}$ for $0.5 \mathrm{~h}$, and $300^{\circ} \mathrm{C}$ for $1 \mathrm{~h}$ under nitrogen atmosphere. IR $(\mathrm{KBr}): v=1774$ and 1712 (imide $\mathrm{C}=\mathrm{O}), 1381(\mathrm{C}-\mathrm{N}) \mathrm{cm}^{-1}$, and $737 \mathrm{~cm}^{-1}$ (imide ring deformation). Anal. Calcd for $\left(\mathrm{C}_{34} \mathrm{H}_{32}-\right.$ $\left.\mathrm{N}_{2} \mathrm{O}_{6} \cdot 0.053 \mathrm{H}_{2} \mathrm{O}\right)_{n}: \mathrm{C}, 72.32 ; \mathrm{H}, 5.71 ; \mathrm{N}, 4.96$. Found: C, 72.20; H, 5.72; N, 4.95. 


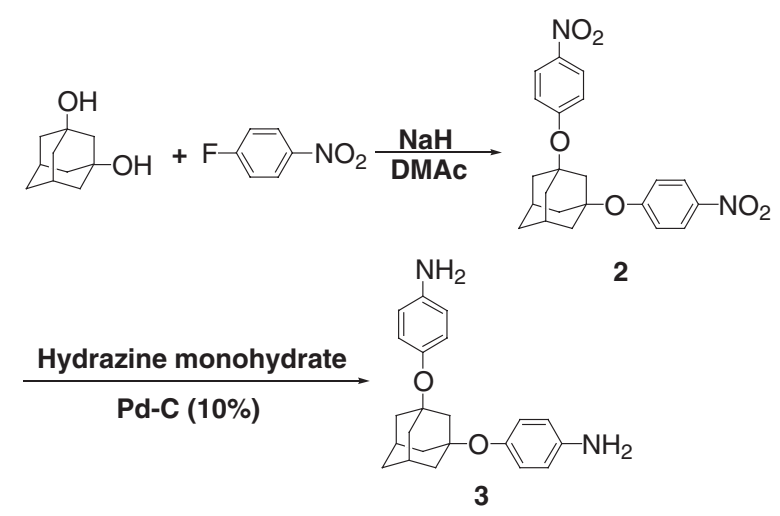

Scheme 1. Synthesis of compound 3.

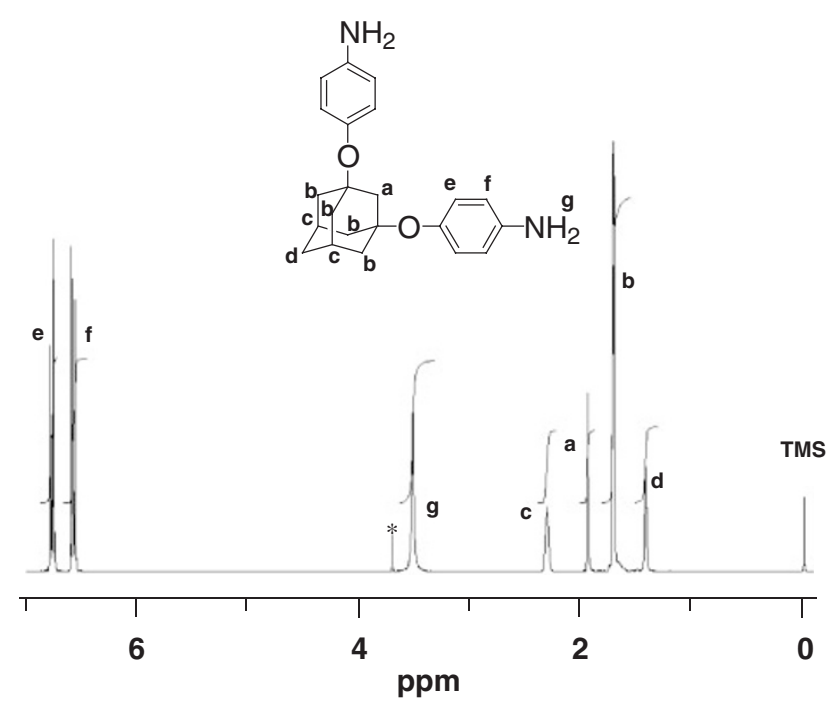

Figure 1. ${ }^{1} \mathrm{H}$ NMR spectrum of 3 in $\mathrm{CDCl}_{3}$ at $25^{\circ} \mathrm{C}$. $*$ Signal at $3.70 \mathrm{ppm}$ was assigned to protons of dioxane.

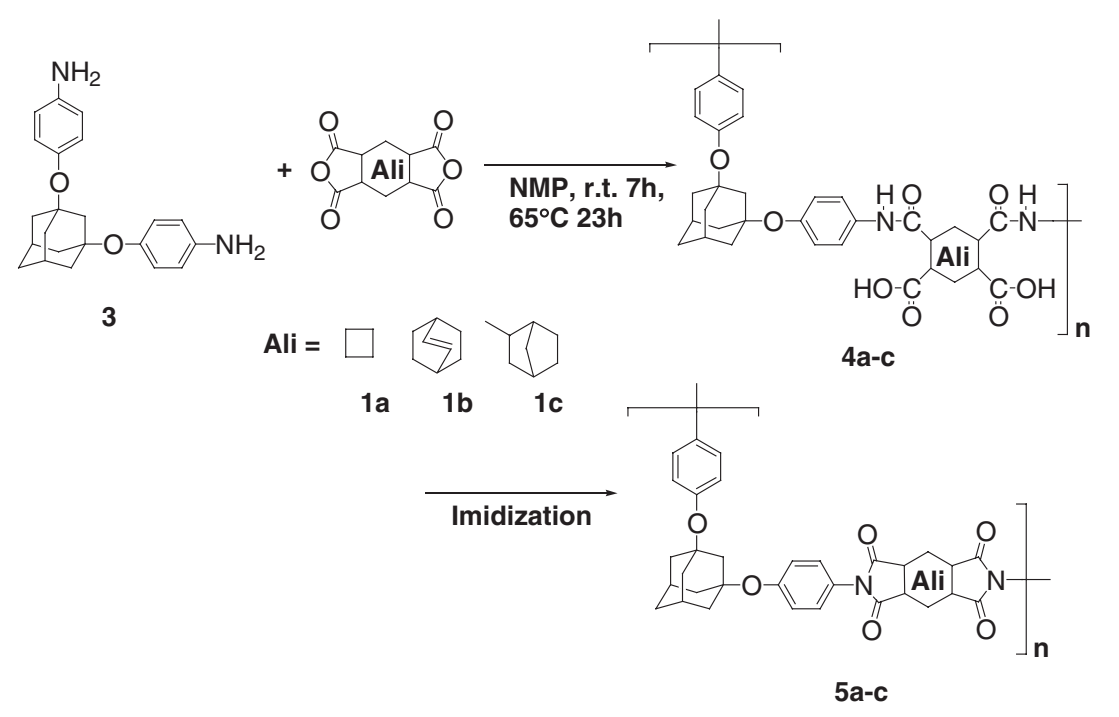

Scheme 2. Synthesis of polyimide 5a-c.

\section{RESULTS AND DISCUSSION}

\section{Monomer Synthesis}

As a semi-aromatic diamine containing adamantyl units, $\mathbf{3}$ was selected. Diamine $\mathbf{3}$ was prepared from 1,3-adamantanediol in two steps as shown in Scheme 1. Reaction of 1,3-adamantanediol with 4-fluoronitrobenzene in dry DMAc yielded 2, which was hydrogenated to afford monomer 3 . The structure of 3 was confirmed by IR and ${ }^{1} \mathrm{H}$ NMR spectroscopy. The IR spectrum of $\mathbf{3}$ showed characteristic absorptions of amino and ether groups at 3400 and $1200 \mathrm{~cm}^{-1}$, respectively. Elemental analysis also supported the formation of $\mathbf{3}$. The ${ }^{1} \mathrm{H}$ NMR spectrum of $\mathbf{3}$ is presented in Figure 1. All peaks are assigned as shown in the inset of Figure 1.
Synthesis of Polymers

As alicyclic dianhydrides (1), 1,2,3,4-cyclobutanetetracarboxylic dianhydride 1a, bicyclo[2.2.2]oct-7-ene2,3;5,6-tetracarboxylic dianhydride $\mathbf{1 b}$, and bicyclo[2.2.1] heptane-2-methanecarboxylic-3,5,6-tricarboxylic-2,3:5,6-dianhydride 1c were employed. Ring-opening polyaddtions of diamines $\mathbf{3}$ with alicyclic dianhydrides 1 were carried out in NMP at room temperature for $7 \mathrm{~h}$, and then $65^{\circ} \mathrm{C}$ for $23 \mathrm{~h}$. (Scheme 2) The results are summarized in Table I. Polymerizations of 1 with 3 proceeded in homogenous solutions, giving poly(amic acid)s 4 with inherent viscosities ranging between 0.24 and $0.62 \mathrm{dL} / \mathrm{g}$. High molecular weight poly(amic acid) 4a was obtained from 1a with 3 probably because of a high reactivity of 1a compared to that of $\mathbf{1 b}$ and $\mathbf{1 c}$. 


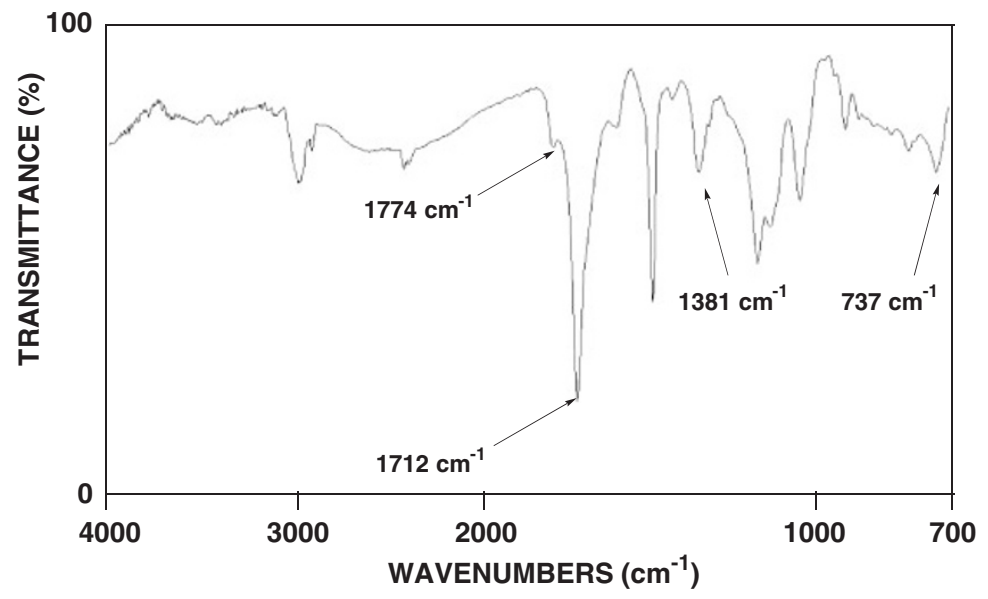

Figure 2. IR spectrum of thermally treated polymer $\mathbf{5 c}(\mathrm{KBr})$.

Table I. Synthesis of Poly (amic acid $)^{\mathrm{a}}$

\begin{tabular}{ccc}
\hline Dianhydride & Polymer & $\begin{array}{c}\text { Inherent } \\
\text { Viscosity } \\
(\mathrm{dL} / \mathrm{g})^{\mathrm{b}}\end{array}$ \\
\hline $\mathbf{1 a}$ & $\mathbf{4 a}$ & 0.62 \\
$\mathbf{1 b}$ & $\mathbf{4 b}$ & 0.24 \\
$\mathbf{1 c}$ & $\mathbf{4 c}$ & 0.33 \\
\hline
\end{tabular}

${ }^{\mathrm{a}}$ Conditions; $1.0 \mathrm{mmol}$ of each monomer in NMP at room temperature for $7 \mathrm{~h}$ then $65^{\circ} \mathrm{C}$ for $23 \mathrm{~h}$ under nitrogen. ${ }^{\mathrm{b}}$ Measured at a concentration of $0.5 \mathrm{~g} /$ $\mathrm{dL}$ in NMP at $30^{\circ} \mathrm{C}$.

\section{Polymer Characterization}

Polymers 4 were identified as the expected poly(amic acid)s by IR spectroscopy. The IR spectra showed characteristic amide and carboxylic acid absorptions at 3317 ( $\mathrm{N}-\mathrm{H}$ and $\mathrm{O}-\mathrm{H}$ str), 1709 (acid, $\mathrm{C}=\mathrm{O}$ str), 1670 (amide, $\mathrm{C}=\mathrm{O}$ str), and $1535 \mathrm{~cm}^{-1}$ (N-H bending).

The thermal imidization of $\mathbf{4}$ to polyimide $\mathbf{5}$ was performed by heating 4 at $70^{\circ} \mathrm{C}$ for $2 \mathrm{~h}, 160^{\circ} \mathrm{C}$ for $1 \mathrm{~h}, 250^{\circ} \mathrm{C}$ for $0.5 \mathrm{~h}$, and $300^{\circ} \mathrm{C}$ for $1 \mathrm{~h}$ under nitrogen atmosphere. The IR spectrum of thermally treated polymer $\mathbf{5 c}$ is shown in Figure 2, where characteristic imide absorptions at 1774 (asym $\mathrm{C}=\mathrm{O}$ str), 1712 (sym $\mathrm{C}=\mathrm{O}$ str), $1381\left(\mathrm{C}-\mathrm{N}\right.$ str), and $737 \mathrm{~cm}^{-1}$ (imide ring deformation) are observed and the absorptions of amic acid groups have completely disappeared. Furthermore, the structure of $\mathbf{5 c}$ was also confirmed by elemental analysis. Thermal properties of the polyimides evaluated by TG and DSC have been listed in Table II. The $5 \%$ weight loss temperatures $\left(T_{\mathrm{d} 5}\right)$ in nitrogen are observed at $380-410^{\circ} \mathrm{C}$. These results show that the thermal stability is lower than that of wholly aromatic polyimides, whereas it is enough for microelectronics applications.
Table II. Thermal Properties of Polyimides

\begin{tabular}{ccc}
\hline Polyimide & $\begin{array}{c}T_{\mathrm{s}}^{\mathrm{b}} \\
\left({ }^{\circ} \mathrm{C}\right)\end{array}$ & $\begin{array}{l}T_{\mathrm{d} 5}{ }^{\mathrm{c}} \\
\left({ }^{\circ} \mathrm{C}\right)\end{array}$ \\
\hline $\mathbf{5 a}$ & 320 & 390 \\
$\mathbf{5 b}$ & 380 & 410 \\
$\mathbf{5 c}$ & 340 & 380 \\
\hline
\end{tabular}

${ }^{a}$ Measured at a concentration of $0.5 \mathrm{~g} / \mathrm{dL}$ in NMP at $30^{\circ} \mathrm{C}$. ${ }^{\mathrm{b}}$ Starting temperature of decomposition.

${ }^{\mathrm{c}}$ Temperature at $5 \%$ weight loss.

Table III. Refractive Indices and Birefringence of Polyimides Films

\begin{tabular}{ccccccc}
\hline Polyimide & $\begin{array}{c}d^{\mathrm{a}} \\
(\mu \mathrm{m})\end{array}$ & $n_{\mathrm{TE}}{ }^{\mathrm{b}}$ & $n_{\mathrm{TM}}{ }^{\mathrm{c}}$ & $n_{\mathrm{AV}}{ }^{\mathrm{d}}$ & $\Delta n^{\mathrm{e}}$ & $\varepsilon^{\mathrm{f}}$ \\
\hline $\mathbf{5 a}$ & 7.1 & 1.5824 & 1.5716 & 1.5788 & 0.0108 & 2.74 \\
$\mathbf{5 b}$ & 2.6 & 1.5759 & 1.5625 & 1.5714 & 0.0134 & 2.72 \\
$\mathbf{5 c}$ & 3.9 & 1.5731 & 1.5703 & 1.5722 & 0.0028 & 2.72 \\
\hline
\end{tabular}

${ }^{\mathrm{a}}$ Film thickness. ${ }^{\mathrm{b}}$ In-plane refractive indices. ${ }^{\mathrm{c}}$ Out-of-plane refractive indices. ${ }^{\mathrm{d}}$ Average refractive index; $n_{\mathrm{AV}}=\left(2 n_{\mathrm{TE}}+\right.$ $\left.n_{\mathrm{TM}}\right) / 3$. ${ }^{\mathrm{e}}$ Birefringence; $\Delta n=n_{\mathrm{TE}}-n_{\mathrm{TM}} \cdot{ }^{\mathrm{f}}$ Optically estimated dielectric constant; $\varepsilon=1.10 n_{\mathrm{Av}^{2}}$.

\section{Dielectric Constant of Polyimides}

As described in Introduction, semi-aromatic PIs can be used as protection and insulation layers in semiconductor field. Thus, it is important to measure $\varepsilon$ of them. The $\varepsilon$ of a polymer film at around $1 \mathrm{MHz}$ can be estimated from the refractive index $n$ according to modified Maxwell's equation, $\varepsilon \fallingdotseq 1.10 n_{\mathrm{Av}}{ }^{23}$ The films of $\mathbf{5}$ on quartz were prepared by spin-cast from DMAc solutions of polymers $\mathbf{4}$, and then these films were heated successively at $70^{\circ} \mathrm{C}$ for $2 \mathrm{~h}, 160^{\circ} \mathrm{C}$ for $1 \mathrm{~h}, 250^{\circ} \mathrm{C}$ for 0.5 , and $300^{\circ} \mathrm{C}$ for $1 \mathrm{~h}$ under nitrogen. Table III summarizes the refractive indices and the dielectric constants of films. The average refractive indices $\left(n_{\mathrm{AV}}\right)$ of polyimides $\mathbf{5 a}, \mathbf{5} \mathbf{b}$, and $\mathbf{5} \mathbf{c}$ were determined as 1.5714-1.5788, respectively. The $n_{\mathrm{AV}}$ of 
1.5714-1.5788 can be translated into dielectric constants of $2.72-2.74$, respectively. These values are lower than the optically estimated $\varepsilon$ of conventional semi-aromatic polyimides $(2.83)^{24}$ and the directly measured $\varepsilon$ of aromatic polyimides containing adamantane $(2.8-2.9$ at $1 \mathrm{KHz}) .{ }^{17}$ Lower $\varepsilon$ values are owed to the introduction of alicyclic imide and adamantyl units that have a lower molar polarization and a larger molar volume compared to those of aromatic imides and phenyl units.

In addition, the in-plane/out-of-plane birefringence $(\Delta n)$ of polyimide $\mathbf{5 c}$ was estimated as 0.0028 . This negligibly small birefringence implies that polyimide $\mathbf{5 c}$ has a low polarizability anisotropy and the polymer chains are randomly oriented in the film. The absence of birefringence was also reported for alicyclic polyimides. $^{24,25}$

\section{Lithographic Evaluation}

The dissolution rate of poly(amic acid)s (PAAs) to $2.38 \mathrm{wt} \%$ aqueous TMAH solution, is too high to get a sufficient dissolution contrast between unexposed and exposed areas. Only one report on the development of PSPI using PAA as a polymer matrix has been reported, where 1,4-dihydropyridine was used as the photosensitive compound. In a preceding paper, we developed a simple PSPI by combination of PAA with a cross-linker and a photoacid generator, and discussed the imaging mechanism in detail. ${ }^{26}$ This finding prompted us to formulate a three-component negative type alkaline developable PSPI precursor based on $\mathbf{4}$, a cross-linker, and a photoacid generator.

As no absorption in the UV-vis absorptions of $\mathbf{4}$ was observed above $350 \mathrm{~nm}$, PTMA having an absorption extending to at $450 \mathrm{~nm}$ was selected as a photoacid generator. On the other hand, MBHP as an acidcatalyzed cross-linker was used on the bases of its availability and high reactivity (Scheme 3 ). To clarify the dissolution behavior of the exposed and unexposed areas (436 nm light), the effects of MBHP loading and post exposure bake (PEB) temperature on the dissolution rate to $2.38 \mathrm{wt} \%$ aqueous TMAH solution using $4 \mathbf{c}$ as a polymer matrix was investigated. The dissolution rate was estimated by measuring the film thickness after development. The effect of MBHP loading after exposure $300 \mathrm{~mJ} / \mathrm{cm}^{2}$ and PEB at $110^{\circ} \mathrm{C}$ for $3 \mathrm{~min}$ was studied, and the results are shown in Figure 3. The dissolution rate of the exposed area decreases with increasing MBHP contents, while the unexposed areas are dissolved in the developer in a $25 \mathrm{wt} \%$ MBHP loading. However, the exposed area is swelled at this loading. A $30 \mathrm{wt} \%$ MBHP loading was appropriate to achieve a good dissolution contrast. To investigate the effect of PEB temperature on the dissolution rate, the dissolution rates of both

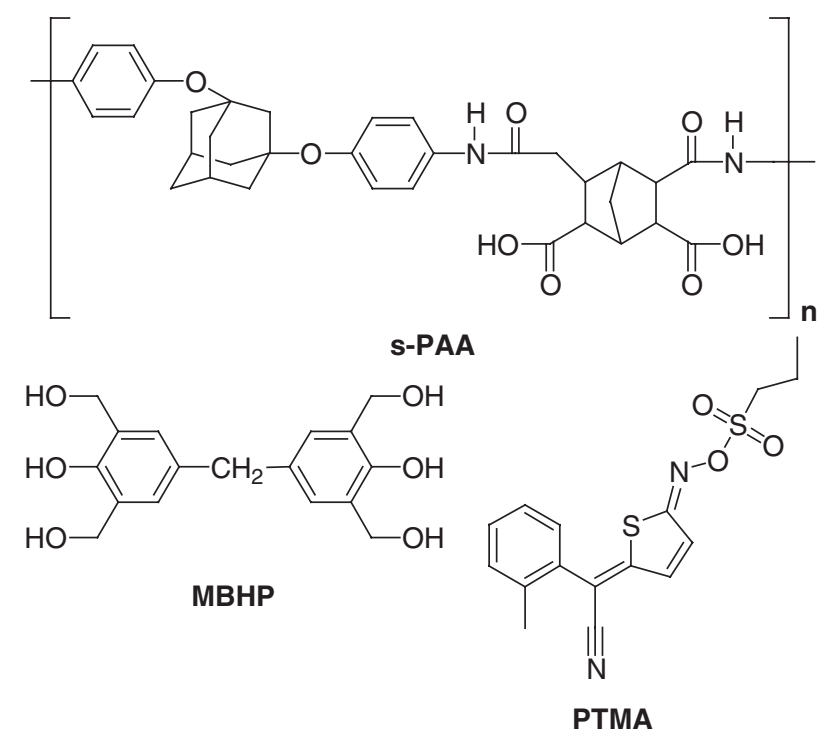

Scheme 3. Poly(amic acid), cross-linker, and photoacid generator.

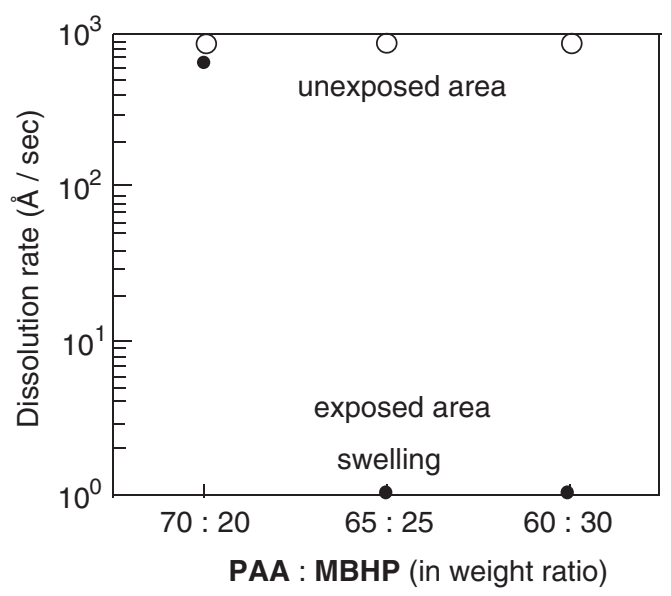

Figure 3. Effect of MBHP loading on the dissolution rate. Component; 20-30 wt \% MBHP, 10 wt \% PTMA, 70-60 wt \% 4c in 2-methoxyethanol. Conditions; prebake at $80^{\circ} \mathrm{C}$ for $5 \mathrm{~min}$, irradiation with $436 \mathrm{~nm}$ light at $300 \mathrm{~mJ} / \mathrm{cm}^{2}$, PEB at $110^{\circ} \mathrm{C}$ for $3 \mathrm{~min}$, development $2.38 \mathrm{wt} \%$ aqueous TMAH solution at $25^{\circ} \mathrm{C}$ for $40 \mathrm{~s}$.

exposed and unexposed areas at various PEB temperatures were plotted. The results in the case of the resist formulated by mixing $4 \mathbf{c}(60 \mathrm{wt} \%)$, MBHP (30 wt \%), and PTMA (10 wt \%) in 2-methoxyethanol are shown in Figure 4, where the film was exposed to $300 \mathrm{~mJ} /$ $\mathrm{cm}^{2}$, post-baked at elevated temperature from 80 to $140^{\circ} \mathrm{C}$ for $3 \mathrm{~min}$, developed with $2.38 \mathrm{wt} \%$ aqueous TMAH solution at $25^{\circ} \mathrm{C}$ for $20 \mathrm{~s}$. The dissolution rate of unexposed region is almost constant up to $120^{\circ} \mathrm{C}$, and suddenly becomes zero at $130^{\circ} \mathrm{C}$ because of thermal cross-linking. On the other hand, the exposed areas are soluble in the developer up to $100^{\circ} \mathrm{C}$, and becomes insoluble at the PEB temperature of $110^{\circ} \mathrm{C}$. Thus, the suitable PEB temperature was determined to be $110^{\circ} \mathrm{C}$. 


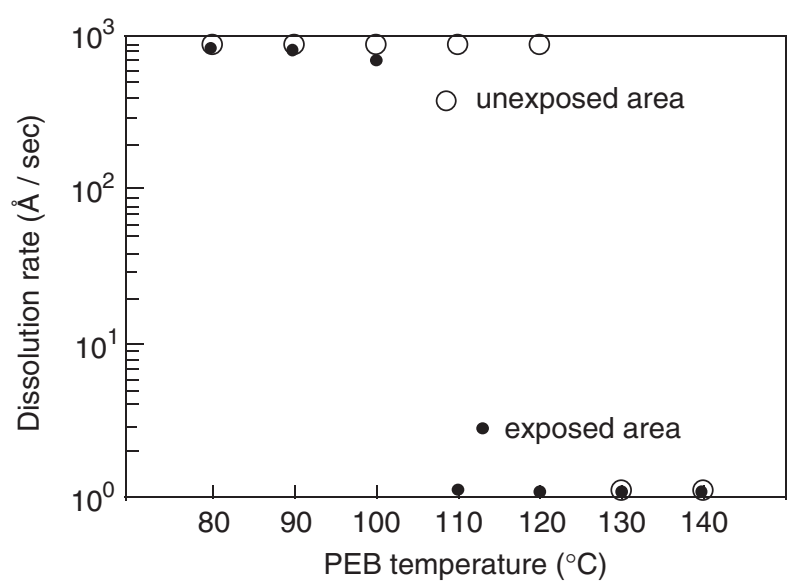

Figure 4. Effect of PEB temperature on the dissolution rate. Component; $30 \mathrm{wt} \%$ MBHP, $10 \mathrm{wt} \%$ PTMA, $60 \mathrm{wt} \% \mathbf{4 c}$ in 2-methoxyethanol. Conditions; prebake at $80^{\circ} \mathrm{C}$ for $5 \mathrm{~min}$, irradiation with $436 \mathrm{~nm}$ light at $300 \mathrm{~mJ} / \mathrm{cm}^{2}$, PEB at $110-140{ }^{\circ} \mathrm{C}$ for $3 \mathrm{~min}$, development $2.38 \mathrm{wt} \%$ aqueous TMAH solution at $25^{\circ} \mathrm{C}$ for $40 \mathrm{~s}$.

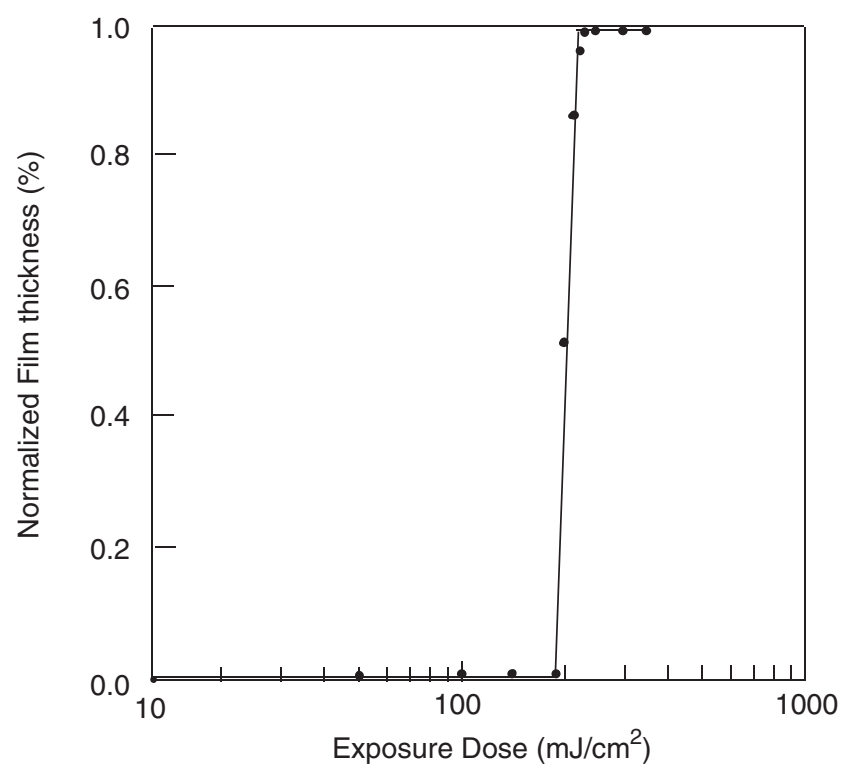

Figure 5. Exposure characteristic curve. Component; $30 \mathrm{wt} \%$ MBHP, $10 \mathrm{wt} \%$ PTMA, $60 \mathrm{wt} \% \mathbf{4 c}$ in 2-methoxyethanol. Conditions; prebake at $80^{\circ} \mathrm{C}$ for $5 \mathrm{~min}, 2.7 \mu \mathrm{m}$ thick film, irradiation with $436 \mathrm{~nm}$ light at $0-300 \mathrm{~mJ} / \mathrm{cm}^{2}$, PEB at $110^{\circ} \mathrm{C}$ for $3 \mathrm{~min}$, development $2.38 \mathrm{wt} \%$ TMAH solution at $25^{\circ} \mathrm{C}$ for $40 \mathrm{~s}$.

After these preliminary optimization studies involving MBHP contents and PEB temperatures, we formulated the PSPI precursor consisting of $60 \mathrm{wt} \%$ of $\mathbf{4 c}$, $30 \mathrm{wt} \%$ of MBHP and $10 \mathrm{wt} \%$ of PTMA. The sensitivity curve of the PSPI precursor film with $2.7 \mu \mathrm{m}$ thickness is shown in Figure 5, indicating that the sensitivity $\left(D_{0.5}\right)$ and contrast $\left(\gamma_{0.5}\right)$ were $210 \mathrm{~mJ} / \mathrm{cm}^{2}$ and 12 , respectively, with $436 \mathrm{~nm}$ light.

Figure 6 presents a scanning electron micrograph of the contact-printed image obtained using the system described above after exposure to $300 \mathrm{~mJ} / \mathrm{cm}^{2}$, devel-

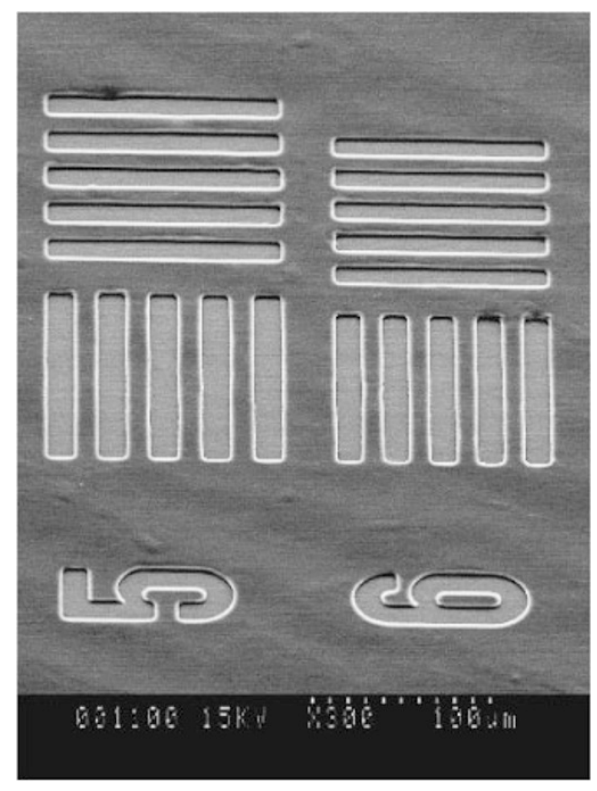

Figure 6. Scanning electron micrograph of a negative image by a contact-printed mode. The $2.7 \mu \mathrm{m}$ thick film (cast from $30 \mathrm{wt} \%$ MBHP, $10 \mathrm{wt} \%$ PTMA, $60 \mathrm{wt} \%$ 4c in 2-methoxyethanol solution and prebaked at $80^{\circ} \mathrm{C}$ for $5 \mathrm{~min}$ ) was exposed with $436 \mathrm{~nm}$ light at $300 \mathrm{~mJ} / \mathrm{cm}^{2}$, developed with $2.38 \mathrm{wt} \%$ aqueous TMAH solution at $25^{\circ} \mathrm{C}$ for $40 \mathrm{~s}$, and rinsed in water.

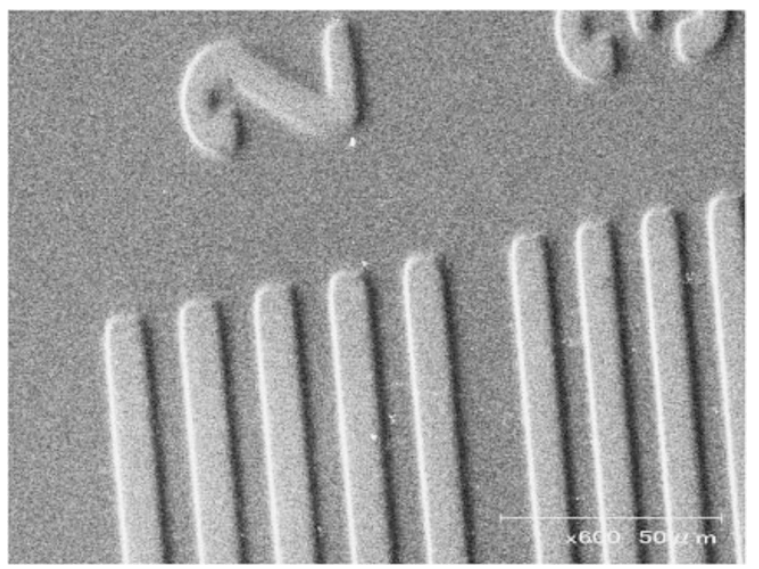

Figure 7. Scanning electron micrograph of PI pattern after curing at $300^{\circ} \mathrm{C}$ for $1 \mathrm{~h}$ in air.

oped with $2.38 \mathrm{wt} \%$ aqueous TMAH solution at $25^{\circ} \mathrm{C}$ for $40 \mathrm{~s}$, and rinsed in water. The clear negative pattern with a $15 \mu \mathrm{m}$ resolution was obtained. This negative image in the film $\mathbf{4 c}$ was converted to that of PI film by high-temperature treatment $\left(300^{\circ} \mathrm{C}\right.$ for $\left.1 \mathrm{~h}\right)$ in air, although some decrease in film thickness and shrinkage of the pattern were observed (Figure 7). The refractive index of the PI film was determined to be 1.5998 , which was translated into the dielectric constant of 2.82 , slightly higher than that of $\mathbf{5 c}$ without additives. Thus, final PI film still exhibited adequate lower $\varepsilon$ value than the other photosensitive PIs. 


\section{CONCLUSIONS}

We have synthesized a novel photosensitive PI with low $\varepsilon$ by introducing semi-aromatic structure in the polymer backbone. The resulting semi-alicyclic PI showed high thermal stability (5\% weight loss temperature was $380^{\circ} \mathrm{C}$ ) and low $\varepsilon$ of 2.72 , estimated from the refractive index. Applying our previously reported method of photosensitive PI fabrication to the current system, the prepared semi-aromatic PI was found to function as a negative-type photosensitive polymer after the addition of a photoacid generator and a cross-linker. The optically estimated $\varepsilon$ of the photosensitive PI film cured at $300^{\circ} \mathrm{C}$ was still 2.82, thus this new system would be useful for low $k$ dielectrics in microelectronic industry.

\section{REFERENCES}

1. M. K. Ghosh and K. L. Mittal, Ed. "Polyimides Fundamentals and Applications," Marcel Dekker, New York, N.Y., 1996.

2. S. Sasaki and S. Nishi, in "Polyimides Fundamentals and Applications,” M. K. Ghosh and K. L. Mittal, Ed., Marcel Dekker, New York, N.Y., 1996, p 71.

3. S. Itamura, M. Yamada, S. Tamamura, T. Matsumoto, and T. Kurosaki, Macromolecules, 26, 3490 (1993).

4. Q. Jin, T. Yamashita, K. Horie, R. Yokota, and I. Mita, J. Polym. Sci., Part A: Polym. Chem., 31, 2345 (1993).

5. Q. Jin, T. Yamashita, and K. Horie, J. Polym. Sci., Part A: Polym. Chem., 32, 503 (1993).

6. M. Yamada, M. Kusama, T. Matsumoto, and T. Kurosaki, Macromolecules, 26, 4961 (1993).
7. T. Matsumoto and T. Kurosaki, Macromolecules, 28, 5684 (1995).

8. T. Matsumoto and T. Kurosaki, Macromolecules, 30, 993 (1997)

9. T. Matsumoto and C. Feger, J. Photopolym. Sci. Technol., 11, 231 (1998).

10. T. Matsumoto, High Perform. Polym., 11, 367 (1999).

11. T. Matsumoto, Y. Maeda, and N. Takeshima, J. Photopolym. Sci. Technol., 13, 327 (2000).

12. J. A. Moore and A. N. Dasheff, Chem. Mater., 1, 163 (1989).

13. J. A. Moore and D. R. Gamble, Polym. Eng. Sci., 32, 1642 (1992).

14. H. Okita, A. Tsuchida, M. Yamamoto, J. A. Moore, and D. R. Gamble, Macromol. Chem. Phys., 197, 2493 (1996).

15. Y.-T. Chern and H.-C. Shieu, Macromol. Chem. Phys., 199, 963 (1998).

16. Y.-T. Chern and H.-C. Shieu, Macromolecules, 30, 4646 (1997).

17. Y.-T. Chern, Macromolecules, 31, 1898 (1998).

18. Y.-T. Chern, Macromolecules, 31, 5837 (1998).

19. Y.-T. Chern and H.-C. Shieu, Macromolecules, 30, 5766 (1997).

20. Y.-T. Chern and H.-C. Shieu, Chem. Mater., 10, 210 (1998).

21. T. Asakura, H. Yamato, and M. Ohkawa, J. Photopolym. Sci. Technol., 13, 223 (2000).

22. N. Takeda and E. Ishimaru, Jpn. Kokai, Tokkyo Koho, 1983, JP 58, 116, 433.

23. D. Boese, H. Lee, D. Y. Yoon, J. D. Swallen, and J. F. Rabolt, J. Polym. Sci., Part B: Polym. Phys., 30, 1321 (1992).

24. T. Matsumoto, Macromolecules, 32, 4933 (1999).

25. Y. Watanabe, Y. Sakai, Y. Shibasaki, S. Ando, M. Ueda, Y. Oishi, and K. Mori, Macromolecules, 35, 2277 (2002).

26. Y. Watanabe, K. Fukukawa, Y. Shibasaki, and M. Ueda, J. Polym. Sci., Part A: Polym. Chem., 43, 593 (2005). 